\title{
Attitudes Toward Wildlife Species Protection: Assessing Moderating and Mediating Effects in the Value-Attitude Relationship
}

\author{
Michael A. Tarrant \\ University of Georgia \\ Alan D. Bright \\ Washington Stale University \\ H. Ken Cordell \\ USDA Forest Service
}

Abstract: Framed in the cognitive hierarchy approach, we examine (1) the mediating effect of general environmental altitudes and (2) the moderating effect of factual wildlife knowledge on the relationship between values and specific wildlife attitudes (wildlife species prolec(ion). These relationships are assessed across four wildlife constituent groups: (1) consumprive users (anglers and hunters), (2) birders (a nonconsumptive user group), (3) non-hunters, non-anglers, and nonbirders (nonusers), and (4) combined consumplive and nonconsumptive users (anglers, hunters and birders). Twelve hundred and to'enty resdents of the Southern Appalachians completed a telephone suney during the summer of 1995. Overall, respondents demonstrated low knowledge but favorable altitudes regarding wildlife species protection. Resulls provided parial support for a cognitive hierarchy in which general allitudes mediate the relationship between values and specific attitudes, and the existence of knowledge as an external moderating variables. Results are discussed in the contexl of information-processing theories and implications for developing effective fish and wildlife communication strategies are considered.

Keywords: Cognitive hierarchy, environmental attiludes, nildife attiIudes, environmental values, wildlife recreation, nildlife knowledge 
Understanding public attitudes is integral to effective fish and wildlife management for, at least, the following reasons: (I) wildlife agencies are legally mandated to involve publics (and to consider their respective opinions) in the decision-making process (e.g., Magnuson Fishery Conservalion and Management Act, 1976); (2) attitudes predispose behavior (such as generating support for wildlife species protection or controlling detrimental human actions); (3) a changing and more diverse wildlife constituency has made it increasingly difficult to predict human responses to management actions; and (4) managing fish and r.ildlife on an ecosystem basis requires that human dimensions (including public attitudes and values) are considered along with biophysical information. However, while many Americans demonstrate strong emotional attachments to fish and wildlife, the basis for their attitudes is often unclear (Dec ker, Brown, \& Mattfield, 1989; Kellert \& Bemy, 1987; Kellert \& Brown, 1985; Manfiedo, Vaske, \& Decker, 1995; Mangun, 1992). It has been suggested, for example, that public attitudes toward wildlife are "motvated more by myth and bias than by knowledge and informed opinion" (Kellert \& Brown, 1985, p.276). To the extent that attitudes regarding fish and wildlife are influenced by individual values and/or knowledge, public responses to programs and policies may not only be anticipated, but also modified and changed to meet agency directives.

\section{Theoretical Orientation}

Cognitive response theories propose that attitudes (1) are based on values, (2) tend from the general to the specific, and (3) predict future behaviors and intentions (Ajzen \& Fishbein, 1980; Fishbein \& Ajzen, 1975; Hc berlein, 1981; Rajecki, 1982; Tesser \& Shafer, 1990). Such an approach recognizes a hierarc hic al framework in which values provide the basis for forming general attitudes, which in tum elic it specific attitudes. Consistent With the notion of attitude-behavior specific ity (Ajzen \& Fishbein, 1980; W'eigel \& W'eigel, 1978), general attitudes a re considered valid predic tors of general behaviors, while specific attitudes are more strongly related to specific actions. Recent work in fish and wildlife has provided pariial support for a "cognitive hierarchy" in nhich attitudes were found to mediate the relationship between wildlife values and behavioral intentions (Fulton, Manfredo, \& Lipscomb, 1996).

Other nork has suggested that extemal non-atitudinal factors mal afrect the linkiages lxctween values, attitudes and behaviors (Ajzen \& Fishbein, 1980; Schwart \& Tessler, 1972; Zanna, Olson \& Fazio, 1980). In he context of natural resource issues, a c nitic al variable, extemal to one's all ilude toward an issue, is the level of faclual or objeclive knowledge aboul that issue (hellen \& Brown, 1985; Manfredo et al, 1995). As issucs wated to natural resource and wildife management policies become incrcasingly complex, there $\mathbf{i}$ a need $t$ o consure that the public is sufficiently knowledgeable to participate in the decision making process and to have well-informed opinions. From a theoretical perspective, knowledge has been shown to link public values with attitudes and preferences. Pierce, Lovrich, Tsuntani and Abe (1989), for example, found that individuals with higher levels of factual knowledge about the environment possessed attitudes toward environmental policies that were more consistent with their fundamental values, illustrating a moderating cffecl for knowledge. It is not known, however, if knowledge plays a moderating role in the formation of attitudes toward fish and wildlife issues that are based on the values that individuals possess.

Research Objectives

Using the context of wildlife species protection, we examine (1) the mediating effect of general environmental attitudes and (2) the moderat ing effect of knowledge on the relationship between values and specific attitudes. These relationships are assessed across four wildlife constituent groups: (1) consumptive users (anglers and hunters), (2) nonconsumptive users (birders), (3) nonusers (non-hunters, -anglers, and -birders), and (4) combined consumptive and nonconsumptive users (anglers, hunters and birders).

\section{Media ting Role of Attitudes}

A mediating effect occ urs when a variable "accounts for the relation between the predic tor and the c riterion" (Baron \& Kenny, 1986; p. 1176). For example, in the cognitive hierarchy, the impact of values on specific attitudes may be mediated through general attitudes. Three conditions are required for a mediation effect to occur (Baron \& Kenny, 1986; Janes \& Brett, 1984): (1) a signific ant relation between the predictor (e.g., values) and the mediator (general attitudes); (2) a significant relation between the criterion (specific attitudes) and the mediator, and (3) when the effect of the mediator is controlled, the relation between the predictor and the criterion should not be significint (and theoretic ally equal to zero).

Predictor. Values represent fundamental cognitions that transcend specific situations and are assumed to be the foundation for attitudes (Fulion et al., 1996; Heberlein, 1981). At the individual lev'el, there are at leasi tn'o types of values: held and assigned. Held values are modes of conduct (e.g., honesty), end-states (e.g., equality), or qualities (e g., beaury) that individuals possess (Rokcach, 1973). Assigned value refers 10 the relative worth or imponance of an object (or thing) relative to other objects (Brown, 1981). The two value types are not independent and it has been argued that assigned values reflect a person's held values (Bengston, 1994; Brown, 1984). There is precedence for measuring assigned value in matural resource (Bengston, 1994) and mijdlife management (Purdy \& Decter, 1989; Stcinhoff, 1980). In the prescnt sludy', we measurc assigned value loward the natural environment, lecause this represcents a basiccore value that is likely to influence attitudes loward specific environmental issues such as wildlife species prolecion. 
Crilerion. Understanding public opinions about specific issues can assist managers to develop communication strategies aimed at producing more favorable support for policy actions, expand into new program areas, and identify new user constituencies (Kellert \& Berry, 1987; Purdy \& Decker, 1387). In the present study, we examine the basis for public attitudes toward wildlife species protection.

Medialor. In the cognitive hierarchy approach, general attitudes are proposed to mediate the relationship between values and specific attitudes (Fishbein \& Ajzen, 1975; Fulton et al., 1996; Heberlein, 1981). In the context of fish and wildlife management, general attitudes might refer to broadly held beliefs about natural resources and the physical environment. Since the early 1970s, several scales to assess public attitudes toward general environmental issues have been developed (e.g., Dunlap \& Van Liere, 1978; Maloney, Ward \& Braucht, 1975; Roper Organization, 1990; Stern, Dielz \& Kalof, 1993; Weigel \& Weigel, 1978).

\section{Moderating Effect of Knowledge}

A moderating effect occurs when the predictor-criterion relationship changes as a function of an external factor (Baron \& Kenny, 1786; Hines, Hunger-ford \& Tomera, 1987; Iwasaki \& Mannell, 1996). For example, knowledge may be considered a moderator if the relation between values and specific attitudes is significantly different (in magnitude and/or direction) for low versus high knowledge groups. Ideally, the moderator should be uncorrelated with the predictor and the criterion (Baron \& Kenny, 1986).

The American public has been shown 10 exhibit generally low levels of factual knowledge regarding environmental (Council on Environmental Quality, 1980; Kuklinski, Mellay \& Kay, 1982) and fish and wildlife (Keller-t \& Brown, 1985) issues. Furthermore, knowledge is, at best, only slightly related (with correlations less than .30) IO both environmental values and attitudes (e.g., Arcury, 1990; Borden \& Schettino, 1979; Cohen, 1373; Dahlgren, W' W'ialon'ski, Dubolz \& Wright, 1977; Maloney \& Ward, 1973; Maloney et al., 1975; Morgan \& Gramman, 1787; Ramsey \& Rickson, 1976; 1977). Morgan and Gramman (1989), for example, found that students' knowledge of snakes explained less than $4 \%$ of the variance in their attitudes toward snakes; while, Dahlgren et al. (1977) reported a correlation of .27 for wildlife knowledge and attitudes toward hunting. While the lack of a strong relationship berween knowledge and values or attitudes has important implications for fish and wildlife management, it does not negate the hypothesis that knowledge may moderate the value-attitude relationship. This hypothesis is important to examine because, if supported, it suggests that values provide a foundation for forming attitudes toward fish and wildlife issues that are dependent upon an individual's level of knowledge about the issue. In other words, individuals n'ith greater knowledge may possess attitudes toward fish and wildlife iss!!ıs that are more in line with their basic values.

\section{Wildlife Constituency}

Values, attitudes and knowledge are experience dependent (Dunlap \& Heffernan, 1975; Kellert, 1984; Newhouse, 1989; Zanna \& Rempel, 1988). Kellert (1984), for example, found that children who watched birds and/or hunted were more knowledgeable and concerned about wildlife than children who did not bird or hunt. Similarly, fishing experience was the strongest predictor of preferences for fish management strategies (Schoolmaster \& Frazier, 1985). These findings suggest that the mediating effect of general attitudes, and the moderating role of knowledge, on the value-specific attitude relationship is likely to be determined by the type of user group. The wildlife constituency consists of traditional consumptive users (hunters and anglers), nonconsumptive users (e.g., birdwatchers, fish-watchers) and the non-utilizing public (Kellert \& Brown, 1985). The recent National Survey on Recreation and the Environment (1995) reports that in a 12-month period, 27.0\%, 29.1\% and 9.4\% of adults ( $>15$ years old) bird-watched, fished and hunted, respectively. In many cases, outdoor recreation activities such as hunting, fishing and birdwatching provide the only context by which individuals experience fish and wildlife resources.

\section{Methods}

\section{Sampling}

Twelve hundred and twenty telephone interviews with household residents of the Southern Appalachians (SAs) were conducted during the summer of 1975 by the Human Dimensions Research Laboratory at the University of Tennessee. The SAs is an area extending south of the Potomac River to northeast Alabama and northern Georgia, and includes the mountain and valley regions of Virginia, West Virginia, North Carolina, Tennessee, South Carolina, Georgia and Alabama. Respondents were selected by asking for the individual in the household with the most recent birthday. Telephone numbers were generated using the random-digit dialing method. A quota sampling procedure was used IO ensure an equal sample size (approximately 600) for both rural and urban residents.

\section{Variable Measurement}

Objective knowledge of wildlife species protection was measured using five "true/false/don't know" statements developed in cooperation with representatives of state and federal fish and wildlife agencies in the SAs (Table 1). Correct responses were scored as one and incorrect responses (including “don't know”) received zero. Knowledge scores ranged from zero to five.

Assigned value of the environment was measured by asking subjccis I0 rank four issues in order of personal importance: "reducing the national debt," "protecting and rehabilitating the natural environment," -reforming 
Table 1

Frequency of Responses to Factual Knowledge of Wildlife Species Protection

\begin{tabular}{|c|c|c|c|}
\hline \multirow[b]{2}{*}{ Statement (with comect response) } & \multicolumn{3}{|c|}{ \% Reporting } \\
\hline & True & False & $\begin{array}{l}\text { Don't } \\
\text { Knnin' }\end{array}$ \\
\hline $\begin{array}{l}\text { Both plants and animals are included on the } \\
\text { Threatened and Endangered Species List (True) }\end{array}$ & 72.3 & 12.6 & 15.1 \\
\hline $\begin{array}{l}\text { A threatened species is one that is near extinction } \\
\text { [False) }\end{array}$ & 69.5 & 16.6 & 13.9 \\
\hline $\begin{array}{l}\text { In Southem Appalachia. more animals and fish } \\
\text { are killed by hunting and fishing than from } \\
\text { removal of habitar [False) }\end{array}$ & 37.5 & 38.9 & 23.7 \\
\hline $\begin{array}{l}\text { In Southem Appalachia. more species of fish, } \\
\text { crayfish and mussels are threatened and } \\
\text { endangered than species of mammals such as } \\
\text { bears and wolves (True] }\end{array}$ & 43.7 & 21.8 & 34.5 \\
\hline $\begin{array}{l}\text { Rainbow trout are native fish in Southem } \\
\text { Appalachia (Fa/se) }\end{array}$ & 51.6 & 18.6 & 298 \\
\hline
\end{tabular}

national health care," and "reducing crime." Items were randomly ordered when presented lo respondents. A score of four was assigned when the respondent indicated the environment was of most importance, a score of three when the environnent was rated as the second mosl important issue, in:o for the third, and onc for when the environment was considered lo be the least imponant of the four issues.

General environmental attitude was measured using one of the following five scales: the New Environmental Paradigm (NEP) (Dunlap \& V'an Liere, 1978), the Environmental Concem (EC) scale (Weigel\& Weigel, 19:8), Awareness of Consequences (AC) scale (Siern, et al., 1993), a modified version of the Forest Values (FV) scale (inserting the word "environment" for "forest") (Steel, list \& Schindler, 1994) and an cnvironmental perceptions sc ale developed by the RoperOrganization (ROPER) (1990). All scales used the same five-point "strongly agree" to "strongl) di sagree" scale with a mid-point of "neither." Respondents nic re randomly ad ministered one of the scalcs. Although previous research by Tarrant and Cordell (in press) has found the fire environmental scales to be moderally related $n$ ith a general environmental behavior index (r's ranging from .27 to .48 ) implying a degree of predictive validity, intercorrclations an ong the environmental scales were not measured and construct validity could not be detemined. For this reason, the five scales riere treated separately in the present sudy.

Allitude toward wildlife species protection was assessed using an index of fourstatements (Table 2) thatwere identified by fish and wildlife experts in the SAS region as being of critical importance lo managers. A five-point "strongly agree" to "strongly disagree" scale, with a mid-point of "neither" was used. Scores on the index could range from four (most s(rongly' disagree) to $\mathbf{2 0}$ (most strongly agree).

Table 2

Frequency of Responses to Attitudes Toward Wildlife Species Protection

$\%$ ReDortin

Statement

Agree Disagree Neither

Land that provides critical habitat for plant and animal species should notbe developed

$\mathbf{7 2 . 5} \quad 22.5$

The Endangered Species Act has gone too far and should be restricted'

It is more important to protect habitat for trout than nongame fish'

More fish should be stocked in streams and lakes to provide increased sportfishing opportunities'

' Items reverse coded.

All respondents were asked (on a dichotonous "yes/no" scale) if they had, in the past year, watched birds, hunted, and/or fished. The nonuser group was comprised of respondents who did not reporl paricipation in any of these three aclivities. The nonconsumplice recreation group included only those who w'alched birds and did nol hunt and 'or fish.' The consumptive group was made up of hose who hunted and ior fished but did not watch birds. Respondents who hunled and/or fished and walched birds comprised the combined consumptive/nonconsumplive recreation group.

Analysis

All analyses were conducted using SPSS/PC+ I'ersion 4.01 (Norusis, 1991) with a significance level of $p=0$. To lest for mediation of general environmental attitudes on the relationship (xetween assigned environ- 
mental value (predictor) and attitudes toward wildlife species protection (criterion) (objective $* 1$ ), a series of regression equations were performed (see Baron \& Kenny, 1986) in which (1) criterion was regressed on the predictor to establish a relationship between these two factors, (2) the mediator was regressed on the predictor to test for condition I necessary for mediation, and (3) the criterion was regressed on both the predictor and the mediator to test for conditions 2 and 3 for mediation. To determine mediation, the relationship between the predictor and the criterion must be less in (3) than in (1). This procedure was conducted for each of the four wildlife constituent groups.

To examine the effect of knowledge as a moderator on the valueattitude relationship (objective $* 2$ ), a test of the correlation coefficients for the two levels of the moderator thigh versus low knowledge) was performed using the Fisher's Z-transformation.' First, knowledge was coded as a dichotomous variable (low versus high) based on scores either below or above the median value (2.0) for the five-item knowledge scale. Second, coefficients between the predictor and the criterion were determined for the low and high knowledge groups. Third, the coefficients were transformed to z-scores and a test of the difference between the two correlations (high versus low knowledge) was conducted. This procedure was undertaken for each of the wildlife constituent groups.

\section{R esults}

\section{Response Rate}

Almost 6,000 telephone numbers were generated during the data collection period. One-fifth $(21.1 \%)$ were disconnected numbers and $9.7 \%$ were business or fax numbers. In total, 2,829 people were contacted. Of these, $54.4 \%$ refused to participate in the survey and $1.8 \%$ terminated partway through the interview. A total of 1,220 people completed the telephone survey (response rate of $43.8 \%$ ). Of these, $20.3 \%(\mathrm{n}-248)$ were birders, $25.4 \%(\mathrm{n}=310)$ hunted and/or fished, $27.0 \%(\mathrm{n}-329)$ were nonusers, and $27.3 \%(\mathrm{n}=333)$ birded and hunted and/or fished.

\section{Descriptive Results}

Correct responses to each of the five objective knowledge statements ranged from $16.6 \%$ ("a threatened species is one that is near extinction") to $72.3 \%$ (both plants and animals are included on the Threatened and Endangered Species List") with a mean score of 1.90 and a median of 2.0 out of 5.0 (Table 1). The environment was rated as the most important issue for $19.0 \%$ of subjects, second for $27.6 \%$, third for $35.2 \%$ and of least importance for $\mathbf{1 8 . 2 \%}$. (The item perceived as the most important overall mas reducing crime.) Generally, respondents indicated a strong positive altitude toward the environment; mean scores and standard deviations for the five scales were: NEP $(3.69, .42), \operatorname{EC}(3.57, .55), \operatorname{ROPER}(3.34, .30)$, AC
(3.93, .30), and FV (3.26, .24). Reliability estimates (measured using Cronbach's alpha) for the five environmental attitude scales were moderate to low: .75 (NEP), .78 (EC), .72 (AC), .55 (FV), and .58 (ROPER) Overall, respondents demonstrated a mixed attitude toward wildlife species protection (Table 2). Almost three-quarters thought that critical habitats should not be developed, but over one-third felt that the Endangered Species Act should be restricted. Most (53.0\%) agreed that nongame fish habitat should be protected over habitat for trout, yet, almost two-thirds supported the stocking of fish to increase sport fishing. The mean attitude score was 12.97 out of 20.0 (S.D. $=2.61$ ).

\section{Differences in Wildife Constituent Groups}

Table 3 shows that birders demonstrated significantly more favorable attitudes toward wildlife species protection than consumptive users; greater knowledge, more favorable attitudes toward wildlife species protection, and stronger environmental values than nonusers; and more favorable attitudes toward wildlife species protection than those who birded and hunted and/or fished. There were no significant differences between consumptive users and nonconsumptive users in their levels of knowledge and assigned environmental values. Users who participated in both consumptive and nonconsumptive activities demonstrated significantly higher levels of knowledge than any other group and stronger environmental values than nonusers; but did not differ from hunters/ anglers or birders on environmental values. Differences in environmental attitudes across the four groups were observed for only one of the five scales (EC), where birders exhibited significantly more favorable environmental attitudes than consumptive users or nonusers.

\section{Objective \#1}

Table 4 shows the results of mediation analysis. The purpose of this analysis was to examine whether the three conditions necessary for mediation were met. Three regressions were conducted for this analysis. Regression 1 establishes a relationship between the predictor (assigned value) and the criterion (specific wildlife attitude). For 311 groups, there was a significant relationship at $p<.001$ (r's ranging from .20 10.40). TO test for mediation, two additional regressions are required to ensure that all three conditions necessary for mediation are mel. Regression 2 establishes a relationship betneen the predictor (assigned value) and the potential mediator (general environmental attitudes). For nonconsumptive, consumptive and nonconsumptive/consumplive users, significant relationswere found for three 10 four of the five scales used, partially satisfying the first condition for mediation. For nonusers, only two of the five environmental attitude scales produced significant relations.

To examine the final two conditions for mediation, the criterion (specific wildlife attitude) is regressed on both the potential mediator (general environmental attitudes) (regression 3:a) and the predictor (assigned valuc) (regression 3b). Regression $3 a$ was satisfied, generally, 
Table 3

A Comparison of Nonconsumptive (Birders'), Consumptive (Hunters' and Anglers'), Nonusers', and Combined Consumptive/Nonconsumptive Users' Wildlife Attitudes, Wildlife Knowledge,

Assigned Environmental Values, and Environmental Attitudes.'

\begin{tabular}{|c|c|c|c|c|c|c|c|c|c|c|}
\hline & \multicolumn{2}{|c|}{$\begin{array}{l}\text { Nonc onsumptive } \\
\text { (birders }\end{array}$} & \multicolumn{2}{|c|}{$\begin{array}{c}\text { Consumptive } \\
\text { (Hunters/anglers) }\end{array}$} & \multicolumn{2}{|c|}{ Nonusers } & \multicolumn{2}{|c|}{$\begin{array}{c}\text { Consumptive/ } \\
\text { Nonconsumptive }\end{array}$} & \multirow[b]{2}{*}{$\mathrm{F}$} & \multirow[b]{2}{*}{$P$} \\
\hline & Mean & S.D. & Mean & S.D. & Mean & S.D. & 5.0. & Mean & & \\
\hline $\begin{array}{l}\text { Wildlife attitudes' } \\
\text { Wildlife knowledge' } \\
\text { Assigned environmental values' } \\
\text { Envrronmental attitudes }\end{array}$ & $\begin{array}{r}13.58^{\circ} \\
1.86^{\circ} \\
2.56^{\circ}\end{array}$ & $\begin{array}{l}2.70 \\
1.25 \\
1.02\end{array}$ & $\begin{array}{r}12.69^{\circ} \\
1.94^{\circ} \\
2.55^{\circ}\end{array}$ & $\begin{array}{l}2.56 \\
1.84 \\
1.00\end{array}$ & $\begin{array}{r}12.91^{\circ} \\
1.56 \\
2.20^{\circ}\end{array}$ & $\begin{array}{r}2.58 \\
1.03 \\
0.96\end{array}$ & $\begin{array}{c}12.85^{\prime} \\
2.22^{\prime} \\
2.60^{\circ}\end{array}$ & $\begin{array}{l}2.55 \\
1.22 \\
0.98\end{array}$ & $\begin{array}{r}4.99 \\
18.35 \\
10.65\end{array}$ & $\begin{array}{r}.002 \\
<.001 \\
<.001\end{array}$ \\
\hline $\begin{array}{l}\text { NEP } \\
\text { EC } \\
\text { ROPER } \\
\text { AC } \\
\text { FV }\end{array}$ & $\begin{array}{l}3.62 \\
3.77^{\circ} \\
3.38 \\
4.06 \\
3.38\end{array}$ & $\begin{array}{l}0.63 \\
0.40 \\
0.47 \\
0.44 \\
0.57\end{array}$ & $\begin{array}{l}3.77 \\
3.50 " \\
3.34 \\
3.88 \\
3.21\end{array}$ & $\begin{array}{l}0.41 \\
0.46 \\
0.60 \\
0.48 \\
0.42\end{array}$ & $\begin{array}{l}3.57 \\
3.47 \\
3.30 \\
3.86 \\
3.15\end{array}$ & $\begin{array}{l}0.48 \\
0.37 \\
0.40 \\
0.52 \\
0.40\end{array}$ & $\begin{array}{l}3.75 \\
3.68^{2.0} \\
3.34 \\
3.90 \\
3.28\end{array}$ & $\begin{array}{l}0.50 \\
0.54 \\
0.39 \\
0.46 \\
0.36\end{array}$ & $\begin{array}{l}2.02 \\
4.21 \\
0.24 \\
2.17 \\
2.37\end{array}$ & $\begin{array}{l}.113 \\
.007 \\
.870 \\
.093 \\
.071\end{array}$ \\
\hline
\end{tabular}

Different alphabetic al superscripts refer to signific ant differences in mean scores

2 Attitudes toward wildlife species protection measured on a response scale of 4 (strongly disagree) to 20 (strongly agree)

${ }^{3}$ Knowledge of wildlife species protection measured on a response scale of 0 (no knowledge) to 5 (high knowledge)

4 Assigned environmental value measured on a response scale of 1 (least important) to 4 (most important)

${ }^{3}$ General emvironmental attitude scales measured on a response scale of 1 [strongly disagree) to 5 [strongly agree]

Table 4

Mediating Effect of General Environmental Attitudes on the Relationship between Assigned Environmental Values and Attitudes toward Wildlife Species Protection

by Wildlife User Constituent Group

Regression 1 (predictor and criterion]

Regression 2 [predictor and mediator)

EC

ROPER

AC

FV

Regression 3a (mediator and criterion)

NEP

ROPER

ACV

Regression 3b (predictor and criterion)

AICD

RQPER

AC

FV

p<.05

" $\mathrm{p}<0$
Nonconsumptive

(birders)

Beta $\mathrm{n}$

$40 * \cdots \quad 201$

$.57 * . \quad 31$

$16 \quad 28$

48 * ** 41

$56^{\circ} 54$

$53: \div \quad \frac{3}{2} 6$

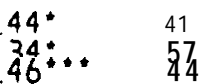

$18 \quad 31$

$24 \quad 28$

$\begin{array}{ll}.21 & 41 \\ 22 & 57\end{array}$

31.44

\section{Consumptive} hunters/anglers

Beta $\mathrm{n}$

$20 * 268$

$.25 \quad 60$

$.36^{\circ} \quad 48$

$48 * \quad 53$

.3ิ * 60

$.36 * 60$

$46 * 48$

$.75 \cdots 53$

$65 \ldots 66$

29. 60

.01

.15

.09

03

48

47

60

\begin{tabular}{lc}
\multicolumn{2}{c}{ Nonusers } \\
Beta & $\mathrm{n}$ \\
$.37 * *$ & 247 \\
& \\
$.39 * *$ & 53 \\
.13 & 60 \\
.26 & 52 \\
$.42 * *$ & 45 \\
.21 & 37
\end{tabular}

$.33^{\circ} \quad 53$

$54 \cdots 60$

$.344^{\circ} \quad 52$

$33^{\circ} \quad 45$

$.53^{*} \quad 37$

$19 \quad 53$

$38^{\circ} \quad 60$

52

$.30 \quad 45$

$27 \quad 37$
Consumptive/ Nonconsumptive

Beta $n$

$.24 * * \quad 281$

$53 * * \quad 5 ; 5$

.42 ** 43

$35^{\circ} \quad 52$

39 " 62

$.18 \quad 69$

$.64 \cdots$

$.65 \cdots \quad 43$

$.27 \quad 52$

$.32 \quad 62$

37

\begin{tabular}{lll}
3 & .23 & 55 \\
6 & 10 & 43 \\
2 & .24 & 52 \\
5 & .06 & 62 \\
7 & .12 & 69 \\
\hline
\end{tabular}


for all four groups in that there was a significant relationship between the mediator (general environmental attitudes) and the criterion (specific wildlife attitude) for 17 of the 20 regressions at $p<.05$ (r's ranging from .3310 .75 ). (The three nonsignificant regressions were all greater than 20 .) For condition 3 to be satisfied, the relationship between the predictor and the criterion should not be significant when the mediator is controlled for (regression 3b). Table 4 shows that only three of the 20 regressions in regression $3 \mathrm{~b}$ were significant, suggesting that, in general, environmental attitudes mediated the predictor-criterion relationship for all four wildlife constituent groups.

\section{Objective $\$ 2$}

Table 5 shows predictor-criterion relationships by level of knowledge (low versus high) for each of the four wildlife constituent groups. Overall, correlations were strongest for nonusers. Knowledge proved to be a significant moderator for two of the four groups: consumptive users ( $z\left(r_{1}-\right.$ $\left.\left.r_{2}\right)=2.40\right)$ and combined consumptive/nonconsumptive users $\left(2\left(r_{1}-r_{2}\right)=\right.$ 2.07). For consumptive users, higher levels of knowledge significantly increased the correlation between values and specific attitudes ( $r$ 's $\approx .33$ and .04 for high versus low knowledge groups); for combined user groups, higher levels of knowledge significantly decreased the predictorcriterion correlation (r's $=.17$ and .38 for high versus low knowledge groups).

\section{Conclusions and Discussion}

This study examined (1) the mediating role of general environmental attitudes and (2) the moderating effect of wildlife knowledge on the relationship between environmental values and attitudes toward wildlife species protection across four primary wildlife constituent groups. Results provide partial support for a cognitive hierarchy in which gencral environmental attitudes mediate the relationship between environmental values and specific wildlife attitudes. There is also some support for the existence of knowledge as an external moderating variable. While higher levels of knowledge significantly improved the prediction of attitudes toward wildlife species protection from environmental values for the Iraditional wildlife-consumptive group, the opposite nas true for the combined user group (i.e., lower levels of knowledge improved the valuespecific attitude relationship). Before discussing implications of these findings for fish and wildlife management, at least three limitations to the study should be recognized.

Limitations

First, ne measured only assigned values, not held. While a number of fish and wildlife studies have used this approach (e.g., Purdy \& Decker, 1989; Steinhoff, 1980), including held values would nol only help establish 
the-basis for assigned values in the cognitive hierarchy (Rokeach, 1968), but would also provide information useful for the establishment of ecosystem management that calls for managing natural resources for multiple values (versus uses) (Bengston, 1994). A related concem is the failure to measure wildlife value orientations (i.e., basic beliefs about wildife) as a possible mediator of the assigned value-general attitude relationship (see for example, Fulion et al., 1996). Furthermore, we did not examine the relationship between attitudes and behavior. Clearly, this is an important area for future research.

A second limitation to the study concems the measurement of objective knowledge. Only one group (combined consumptive/ nonconsumptive users) averaged more than $40 \%$ correct responses on knowledge about wildlife species protection. Although this is not inconsistent with other studies that have shown public misconceptions about wildlife (e.g., Kellent \& Bery, 1987; Kellen \& Brown, 1985; Morgan \& Gramman, 1989), there have been studies that have shown public knowledge of natural resources to be quite high (e.g., Reading, Clark \& Keller, 1994). These conflicling findings suggest more work should be directed toward the development of valid knowledge scales (see also Arc ury \& J ohnson, 1988).

Third, it is not knon in to what extent the five environmental scales are comelated and are, therefore, specifically measuring the same latent construct Although predictive validity has previously been demonstrated, the scales may not necessarily be considered similar measures of general environmental attitudes. A related concem is that two of the scales (RorR and modified FV) did not reach acceptable levels of intemal reliability (alpha of 60 or better); however, in both cases the reliability coefficients were very close to .60 .

Conclusions

Attitudes toward wildlife species protection not only reflect assigned environmental values, but are affected by general attitudes toward the environment and, to some extent, wildlife knowledge levels. It is not sumprising that general environmental attitudes acted as a significant mediator because they represent symbolic (i.e., value-laden) beliefs. Such Ixliefs have been found to be important predictors of attitudes lon'ard specific government policies (e.g., Sears, Lau, Tyler \& Allen, 1980) and nolf reintroduction (Bright \& Manfredo, 1996). The moderating role of knowledge is consistent $n$ ith earlier findings that individuals $w$ ith greater $k$ nonledge have attitudes toward environmental policies that are more in line with their fundamental values (e.g., Pierce et al., 1989). There are hoviever, at least in.o fundamental questions that arise from the test for muderation: (1) why is knowledge not a significant moderator for nonusers and birders? and (2) why would increased knowledge reduce the cffect of values on specific attitudes for combined consumplive/ nonconsumptive usergroups?
To address the first question, it is important to recognize that boin nonusers and birders obtained the lowest knonledge scores, suggesting that the difference between high versus low knowledge for these two groups may not have been as great as for hunters/anglers and the combined consumptive/nonconsumptive groups. This lack of statistically significant differences may be a function of the size of the samples. Sample sizes for the high knowledge groups were considerably smaller for both nonusers $(n=58)$ and birders $(n=70)$ than for hunters/anglers $(n=93)$ and combined consumptive/nonconsumptive users $(n * 130)$. This result may also reflect the nature of attitudes of low versus high knowledge individuals. Attitudes of individuals who have low knowledge of an issue (in this study, more likely to be nonconsumptive users and nonusers) may be less formed than attitudes based on high levels of knowledge, making the effects of various extemal factors suc $h$ as knowledge and values on specific attitudes less predictable.

To address the second question, it is important lo recognize the relative importance of the moderator and predictor in explaining variance in the criterion. Moderation occurs because the relation between the predictor and criterion changes as a function of the moderator. In our study, increased knowledge improved the value-attitude relation for consumptive users; i.e., for individuals with higher knowledge levels, attitudes about wildlife species protection were based on, and aligned with, their environmental values. This finding is consistent with previous work (e.g., Pierce et al., 1989). However, for the combined user group, lower (rather than higher) knowledge levels improved the predic tive validity of values; i.e., individuals with higher knowledge relied less strongly on their values to form attitudes about wildlife species protection. $W^{\prime}{ }^{\prime}$ ly did this occ ur? One explanation might be that people who participated in both nonconsumptive and consumptive activities demonstrated such high knowledge scores (relative to the other three wildlife constituent groups) that they relied more heavily on existing knowledge 10 form attitudes; i.e., knowledge functioned as the primary predic tor variable in accounting for variance in specific attitudes. Tyboul and Scoll (1983) have argued that when knowledge is readily available, attitudes are formed b) retrieving stored information about the object/issue. It is likely, therefore, that when knowledge about wildlife species protection is available to respondents, they rely less on assigned values 10 form attitudes about wildlife species protection and rely more on information stored in memory. To test this hypothesis, we conducted additional analysis that examined the effect of both knowledge and assigned value on attitudes toward wildlife species protection using the multiple regression (stepriise) procedure in SPSS/PC+. Results showed that for birders and nonusers, knowledge had lower predictive validity $(r * .16$ and .09 , respec tively) than assigned value $(r=.36$ and .37 , respectively); for anglers/hunters, knonledec and value had similar predictive validity $(r=.17$ and .18 , respectively); while, for combined consumptive/nonconsumptive users, 
Rnowledge had stronger predictive validity $(r=.26)$ than value $(r=.21)$. It is not surprising that people who participate in both consumptive and nonconsumptive wildlife activities rely more on knowledge than values to form specific attitudes about wildlife. Because nonconsumptive users have stronger proenvironmental attitudes (Jackson, 1986) and more preservationist-oriented beliefs about wildlife (Fulton et al., 1996), these two value orientations could produce internal conflict for people who both bird and hunt/fish. Because people are motivated to reduce the cognitive dissonance produced by conflict (Festinger, 1957), one solution is to rely on other sources of information (such as knowledge) to form attitudes.

\section{Implications}

With the growing tendency for the public to become more involved in decisions regarding the management of wildlife resources, there are practical implications to a greater understanding of the relationships among public values, attitudes and knowledge. First, attitudinal information can help managers understand the diverse sides of wildlife management issues. Increasingly, the management of viable natural ecosystems can represent a multiplicity of public values (Bengston, 1994). Given that they must manage natural and wildlife resources in the public interest, managers must recognize the extent to which these values drive public attitudes toward specific issues. In this study, the extent to which values drive attitudes differed between wildlife users and nonusers. This makes reliance on values as a gauge of public attitudes only relevant for groups whose values actually drive their attitudes.

Second, a significant amount of research in social psychology and natural resource management, among others, has supported the notion that attitudes predispose or predict behavior. Such behavior may take an active form, as with appropriate hunting behavior on public lands, or a more passive form, such as support for specific management practices related to fish and wildlife issues. This is important because many decisions regarding wildlife-related issues are being brought forward to the public through ballot initiatives. To illustrate, spring black bear hunting was eliminated by voters in Colorado in 1992. A ballot initiative to forbid the use of hounds and bait for hunting bears passed in Oregon in 1994 and Washington in 1996, and failed in Idaho in 1996. Regardless of the outcome of these initiatives, it is apparent that wildlife managers must understand the nature of public attitudes and the resulting behavior. For example, are attitudes toward hunting techniques related to values based on animal welfare or values based on the perceived role of the public in wildlife management policy making?

Understanding the nature of attitudes is complicated by the moderating effects of knowledge of the issue. This complication occurs for two reasons. First, the relationship between assigned value and attitudes toward the issue were different among consumptive recreation\& de- pending on their level of knowledge of the issue, slightly confounding the issue of what to include in a persuasive communication to this group. Second, communication campaigns may have different effects on knowledgeable recreationists than those with little knowledge independent of the nature of other external factors. Manfredo and Bright (1991) found that knowledgeable users of the Boundary Waters Canoe Area Wilderness were less likely to elaborate on USFS information and be influenced by it than were less knowledgeable users. This suggests that not only is the content of the message provided to different constituencies complicated and problematic, but so is the issue of how to get various groups to even examine the message in the first place.

\section{Endnotes}

1 Although nonconsumptive recreation includes activities other than bird-watching (e.g., fish-watching, viewing wildlife, cross-country skiing, etc.), for the purposes of this study, the term "nonconsumptive recreation" will be used to describe bird-watching.

'The procedure is described in detail in Cohen \& Cohen (1983) and Shavelson (1988).

\section{References}

Ajzen, 1., \& Fishbein, M. (1980). Understanding attitudes and predicting social bebarior. Englewood Cliffs, NJ: Prentice-Hall, Inc.

Arcury, T.A. (1990). Environmental attitude and environmental knowledge. Human Organization, 49(4), 300-304.

Arcury, T.A., \& Johnson, T.P. (1988). Public environmental knowledge: A statewide survey. Joumal of Environmental Education, 19,31-37.

Baron, R.M., \& Kenny, D.A. (1986). The moderator-mediator variable distinction in social psychological research: Conceptual, strategic, and statistical considerations. Joumial of Personality and Sucial Psycbologl, 51(6), 1173-I 182

Bengston, D.N. (1994). Changing forest values and ecosy'siem management. Suciet)' and Nianural Resources, 7, 515-533.

Borden, R.J., \& Schellino, A. (1979). Determinants of environmentally responsible behavior: Facts or feelings? Joumal of Entironmental Education, $.1044), 35-37$.

Bright, A.D., S Manfredo, M.J. (1996). A conceptual model of attitudes toward natural resource issues: A case study of wolf reintroduction. Human Diml'nsions of IIildllife, I( 1) l-17.

Drown, TC. (1984). The concept of value in resource allocation. Lumd Economics, 60(3), 231-246.

Cohen, M.R. (1973). Environmental informalion versus environmental altiludes. The Jutural of Entronmentul Education, 5(2), 5-8.

Cohien, J., \& Cohen, P. (1983). Appliced mulliple regrissiondcurrelation analysis for the bebatioral scicnces (2nd ed.). Hillsdale, NJ: Erlbaum.

Council on Environmental Quality. (1980). Pullic opinion on 'mirumme'ntal issues. Results of a nutional pullic opintion surney. W'asthinglon, D.C.: U.S. Gowernment Printing Office. 
DahIgren, R.B., W'yialouski, A., Bubolz, I A., \& Wrıgli, V.L. (1Y//). nfluence of knowledge of wildlife management principles on behavior and attitudes toward resource issues. Forty-Sicond North Amencan Willdife Conference, 146-I 55.

Decker, D.J., Brown, T.L., \& Mattfeld, G.F. (1989). The future of human dimensions of wildlife management: Can we fulfill the promise? Transactioms of the 54ib North American Wildiffe and Natural Resource Conference, 54, 415-425.

Dunlap, R E., \& Heffernan, R.B. (1975). Outdoor recreation and environmental concern: An empirical examination. Rural Sociology, 40, 18-30.

Dunlap, R.E., \& Van Liere, K.D. (1978). The new environmental paradigm. Jounial of Enironmental Education, 9, 10-19.

Festinger, L. (1957). Theory of cognitlie dissonance. Stanford, CA: Stanford University Press.

Fishbein, M. \& Ajzen, 1. (1975). Belief, altitude, hiention and bebaitor: An introduction to 'theon' and research. Reading, MA: Addison-Wesley.

Fulton, D.C., Manfredo, M.J., \& Lipscomb, J. (1996). Wildlife value orientations. Hitman Dimensions of Wildlife, 1(2), 24-48.

Heberlein, T.A. (1981). Environmental attitudes. Zelischrififur limuelipolitik, 2 241-270.

Hines; J.M., Hungerford, H.R., \& Tomera, A.N. (1987). Analysis and synthesis of research on responsible environmental behavior: A meta-analysis. Joumal of Eniriranmental Education, 18(2), 1-8.

In'asaki, Y., \& Mannell, R.C. (1976). Implications of moderator-mediator analyses in leisure research. Paper presented at The 4tb World Letsure and Recreation Association meeting, July 16-17, Cardiff, Wales.

Jackson, E.L. (1986). Outdoor recreation participation and attitudes to the environment. Leisure Studies, 5, I-23.

James, L.R., \& Brett, J.M. (1984). Mediators, moderators, and tests for mediation. Jounial of Applied Psychology', 69, 307-321.

Kellert. S.R. (1984). Assessing wildlife and environmental values in costbenefit analysis. Journal of Entironmental Management, 18(4), 353-363.

Kellert, S.R., \& Berry, J.K. (1987). Attitudes, knowledge and behaviors toward wildlife as affected by gender. H'ildlife Socicty Bulletin, 15, 363-371.

Kellert, S.R., \& Brown, P.J. (1985). Human dimensions information in wildlife management, policy, and planning. Le'sure Science's, $X 3$ 3), 269-280.

Kuklinski, J.H., Mellay, D.S., \& Kay, W.D. (1982). Citizen knowledge and choices on the complex issue of nuclear energy. American Joumal of Political Scince, 26(4), 615-642.

Maloney, M P., \& U'ard, M.P. (1973). Let's hear it from the people. American Psicbologist, 28, 58,586.

Maloney, M.P., Ward, M.P., \& Braucht, G.N. (1975). A revised scale for the measurement of ecological attitudes and knowledge. American Ps)chologist 3a7), 787-790.

Manfredo, M J.. \& Bright, A.D. (1791). A model for assesing the effects of communication on recrealionists. Joumal of Le'sure Research, 23(1), 1-20.

Manfredo, M.J., l'aske, IJ., \& Decker. D.J. (1905). Human dimensions of wildlife management: Basic concepts. In R.L. Knighı and K.J. Guiznilles (Eds.) Iildalife and Recreationists Covelo, CA: Island Press.

Mangun, W'.R. (Ed ). (1992). American fish and u'lldife policy The l.tuman dimenisiom. Carbondale, IL: Southern Illinois University Press,

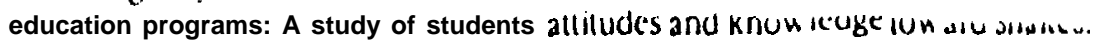
H'ildlife Soci't)' Bulletin, 1 7, 501-509.

National Survey on Recreation and the Environment (1995). USDA Forest Senice and the University of Georgia, Athens, GA. Report in progress.

Newhouse, N. (1989). Implications of attitude and behavior research for environmental conservation. Joumal of Emirommental Education, 20, 27-34.

Norusis, M.J. (1991). SPSS/PC+ (Verston 4.01) I Compuler sofiwarel. Chicago, IL: SPSS Inc.

Pierce, J.C., Lovrich, N P. Tsurutani, T., \& Abe, T. (1789). Public knouledye and entironmentalpolistcs in Japan and ibe Unilced Siates. Boulder, co: Westvicw Press.

Purdy, K.G., \& Decker, DJ. (1989). Applying wildlife values informalion in management: The wildlife attitudes and values scale. Wildlife Sociely' Bulletin, 17. 494-500.

Rajecki, DW. (1982). Altifludes: Themes and adiances. Sunderland, MA: Sinauer Associates, Inc.

Ramsey, C.E., \& Rickson, R.E. (1977). Environmental knowledge and attitudes. Joumal of Entironmental Education, 8(1), 10-18.

Reading, R.P., Clark, T.W. \& Kellert, S.R. (1974). Attitudes and knonledge of people living in the Greater Yellowstone Ecosystem. Suciut)' and Natural Resources, 7, 349-365.

Rokeach, M. (1968). Beliefs, attitudes and zalues: A tbeon' of onganization and change. San Francisco: Jossey-Bass.

Rokeach, M. (1973). The nalure of buman ualues. New York: Free Press.

Roper Organization. (1990). The entironment: Public altitudes and indt-

lidual behavior. New York: The Roper Organization.

Schoolmaster, F.A. \& Frazier, J.W. (1985). An analysis Of angler preferences for fishery management strategies. Leisure Sciences, X3), 321-342.

Schwartz. S.H., \& Tessler, R.C. (1972). A test of a model for reducing measured attitude-behavior discrepancies. Jounial of Personality and Social Psychology, 24, 225-236.

Sears, D.O., Lau, R.R., Tyler, T.R., \& Allen, H.M. (1980). Self-inleresl versus symbolic politics in policy attitudes and presidential voting. The American Polifical Schence Retienu, 74, 670-684.

Shavelson, K.J. (1988). Slatistical rocosoning for the bathol ioral sciences. Needham Heights, MA: Allyn and Bacon.

Steel, B.S., List, P., \& Schindler, B. (1994). Conflicting values aboul federal forests: A comparison of national and Oregon publics. Saclef) and N'atural Rescurces, 7, 137-I 53

Steinhoff, H $W^{\prime}$ (1980). Analysis of major concptual sy'slems for understanding and measuring wildlife values. In $W^{\prime}$. W'. Shaw and E.H. Zube (Fds.), H'ikdlifa lialues. Tuston, AZ: Center for Assessment of Noncommodity Natural Resource values.

Stern, P.C., Dietz, T., \& Kaloff, L. (1993). Value orientations, gender, and environmental concern Emiromm('nf and behasior, 25(3), 322-348.

Tarrani, MA. \& Cordell, HK. (In press). The effect of respondent characleristics on general environmental attitude-behavior correspondence. Enirorime'n! and Bibaitor.

Tesser, A., \& Shaffer, D.R. (1990). Altiludes and attitude cliange Allmual Ricti'u' of Psychology', 41, 479-523. 
- Tyboul, A.M., \& Scott, C.A. (1983). Availability of well-defined internal knowledge and the attitude formation process: Information aggregation versus self-perception. Journal of Personality and Social Psycbology, 44(3), 474-491.

Weigel, R., \& W'eigel, J. (1978). Environmental concern: The development of a measure. Entironmenl and Behattor, 101), 3-15.

Zanna, M.P., Olson, J.M., \& Fazio, R.H. (1980). Attitude-behavior consistency: An individual difference perspective. Jounial of Personality and Social Psycbology, 38, 432-440.

Zanna, M.P., \& Rempel, J.K. (1988). Allitudes: A new look at an old concept. In D. Bar-Tal and A.W. Kruglanski (Eds.), The soctal psychology of knouledge. Cambridge, MA: Cambridge University Press. 